\title{
Studies of actinosporean myxozoan stages parasitic in oligochaetes from the sediments of a hatchery where Atlantic salmon harbour Sphaerospora truttae infection
}

\author{
J. McGeorge*, C. Sommerville, R. Wootten \\ Institute of Aquaculture, University of Stirling, Stirling FK9 4LA, United Kingdom
}

\begin{abstract}
Five different myxozoan actinosporean spore forms of 4 collective groups are described from oligochaete worms obtained from the sediments of a Scottish salmon hatchery where Sphaerospora truttae infections recur annually. Synactinomyxon 'A', synactinomyxon 'B', raabeia, triactinomyxon and aurantiactinomyxon stages are illustrated, characterised and the stimuli for their polar filament release investigated. Each actinosporean is compared with actinosporean 'species' described in the literature and actinosporean stages described from reports of 2 host myxozoan life cycles. Three of the forms reported appear to be previously undescribed.
\end{abstract}

KEY WORDS: Actinosporean Myxosporean Myxozoan Sphaerospora spp

\section{INTRODUCTION}

Perhaps because they infect oligochaete worms, actinosporeans have been regarded since they were first reported by Stolc in 1899 as parasites of little economic significance, and thus are a relatively poorly studied group. However, over the last 15 yr scientific interest in actinosporeans has increased following the discovery that a single myxozoan life cycle exists in which there is alternation between myxosporean and actinosporean stages, in fish and in invertebrate hosts respectively (Wolf \& Markiw 1984). There are currently over 12 reports of such life cycles (El-Matbouli et al. 1995, Kent et al. 1995). Since many myxosporeans cause significant economic impacts and disease both in wild fisheries and in the aquaculture industry, the importance of understanding the role of actinosporeans as the myxozoan stage infective to fish cannot be overemphasised.

\footnotetext{
- Present address: University Secretary's Office, University of Abertay Dundee, Bell Street, Dundee DD1 1HG, United Kingdom. E-mail: anacsjm@tay.ac.uk
}

The class Actinosporea has been recently suppressed, with actinosporean generic names now treated as collective group names to avoid competing in priority with myxosporean generic names. Actinosporeans for which the myxosporean stage is not known are to be retained as species inquirendae until established (Kent et al. 1995). This taxonomic system is adopted in this paper.

There are very few studies reporting actinosporean stages from oligochaetes in the UK (Table 1). Such studies are required to provide important data on the nature and distribution of these poorly understood parasites in UK waters. Further information on the biology of these organisms may provide links to species of myxosporean which currently are, or have the potential to become, important pathogens of wild and farmed fish and such studies may also provide important information with regard to pathogen control in the future.

The present study was initiated to establish the actinosporean fauna of oligochaete worms from an Atlantic salmon farm where infections with Sphaerospora truttae Fischer-Scherl, El-Matbouli \& Hoffmann, 1986 recur annually, in the hope of completing the life cycle 
Table 1. Reports of actinosporeans from oligochaetes in the UK

\begin{tabular}{|lll|}
\hline Source & Actinosporean & Location \\
\hline Ikeda (1912) & Hexactinomyxon sp. & Plymouth, England \\
& Synactinomyxon sp. & \\
& Tractinomyxon sp. & \\
& Sphaeractinomyxon sp. & \\
Mackinnon \& Adam (1924) & Triactinomyxon ignotum & River Thames, England \\
& Triactinomyxon legeri & \\
& Triactinomyxon mrazeki & \\
Hamilton \& Canning (1987) & Synactinomyxon tubificis & Myxobolus cerebralis positive rainbow trout hatchery, south- \\
& Echinactinomyxon radiatum & west England \\
& Triactinomyxon ignotum & \\
& Triactinomyxondubium & \\
& Aurantiactinomyxon sp. & \\
\hline
\end{tabular}

and facilitating control of the parasite. This bivalvulid myxosporean infects juvenile Atlantic salmon Salmo salar L. at a number of smolt-producing hatcheries in Scotland (McGeorge et al. 1994, 1996a, b). During the summer months, the extrasporogonic stages of this parasite have been found to be significant pathogens in Atlantic salmon parr.

\section{MATERIALS AND METHODS}

Oligochaete sampling. Oligochaetes were sampled upstream and downstream of the river supplying a smolt-producing hatchery where salmon become infected each year with Sphaerospora truttae. Sampling was concentrated in the period from March to June when epidemiological studies indicated that the infective stage might be present in the environment (McGeorge et al. 1996a).

Worms were obtained in mid-April, mid-May and mid-June 1992 and in mid-May and mid-June 1993 by kick sampling using a kick net of mesh size $50 \mu \mathrm{m}$ in areas with gravel/rock substrates, and using corers and Peterson grabs where softer sediments were present. The enriched sediments of the farm settlement pond were sampled in mid-May, mid-June and late June 1993. All invertebrates obtained were transferred to plastic bags containing stream water and aerated prior to transport to the laboratory.

Examination of worms and calculation of prevalence of infection. Oligochaetes obtained were examined using the cell-well technique of Yokoyama et al. (1991) Twenty-four-well plates holding 1 to 5 worms of the same species per well in $1 \mathrm{ml}$ of water were exposed to natural temperature and light conditions outdoors, and the water in each well scanned thoroughly by phase contrast microscopy at $\times 250$ magnification for the presence of actinosporeans each day. Worms were monitored for parasite release for $1 \mathrm{mo}$.
Prior to being discarded, a sample of approximately $10 \%$ of these worms were squashed and examined microscopically for actinosporean stages. Prevalence was calculated from each sample for each actinosporean found, as a percentage presence in the entire worm population, regardless of worm species. Prevalence for each actinosporean in each host species was difficult to calculate. The identification of all individual worms studied was not feasible because of the numbers involved, whilst establishing the specific identity of each infected worm was often impossible due to the worm's immaturity.

Identification of worm species. Fifty oligochaetes were identified to obtain details of the relative species composition of the fauna of each habitat studied. Worms were fixed in $70 \%$ alcohol, then subsequently transferred to distilled water via a descending ethanol series before being placed individually onto slides in a few drops of Amman's lactophenol, covered with a coverslip and left for several hours to clear (Brinkhurst 1963). Prior to examination, slight pressure was exerted on the coverslip to flatten the mount. Mounts were examined at appropriate magnification and worms identified using the key of Brinkhurst (1963).

Actinosporean morphology and identification. Actinosporean stages were drawn and photographed under bright field, phase contrast and Nomarski interference contrast microscopy. Measurements taken for each spore type are illustrated in Fig. 1 and were made from at least 15 randomly selected spores using a micrometer calibrated eye-piece graticule or from enlarged photomicrographs of known magnification. Spores obviously dead or senescent, and those not yet fully mature, were not measured. Spores were identified using the keys and diagrams of Janiszewska (1955, 1957), Marques (1984) and by comparison with other published reports. Some infected worms were squashed between a coverslip and a slide to reveal the nature of the pansporocyst. 
Fig. 1. Drawings of spore forms for actinosporeans found during the study. (A) synactinomyxon 'A', (B) synactinomyxon ' $B$ ', (C) triactinomyxon, (D) raabeia, (E) aurantiactinomyxon. (Scale $\mathrm{bar}=10 \mu \mathrm{m})$
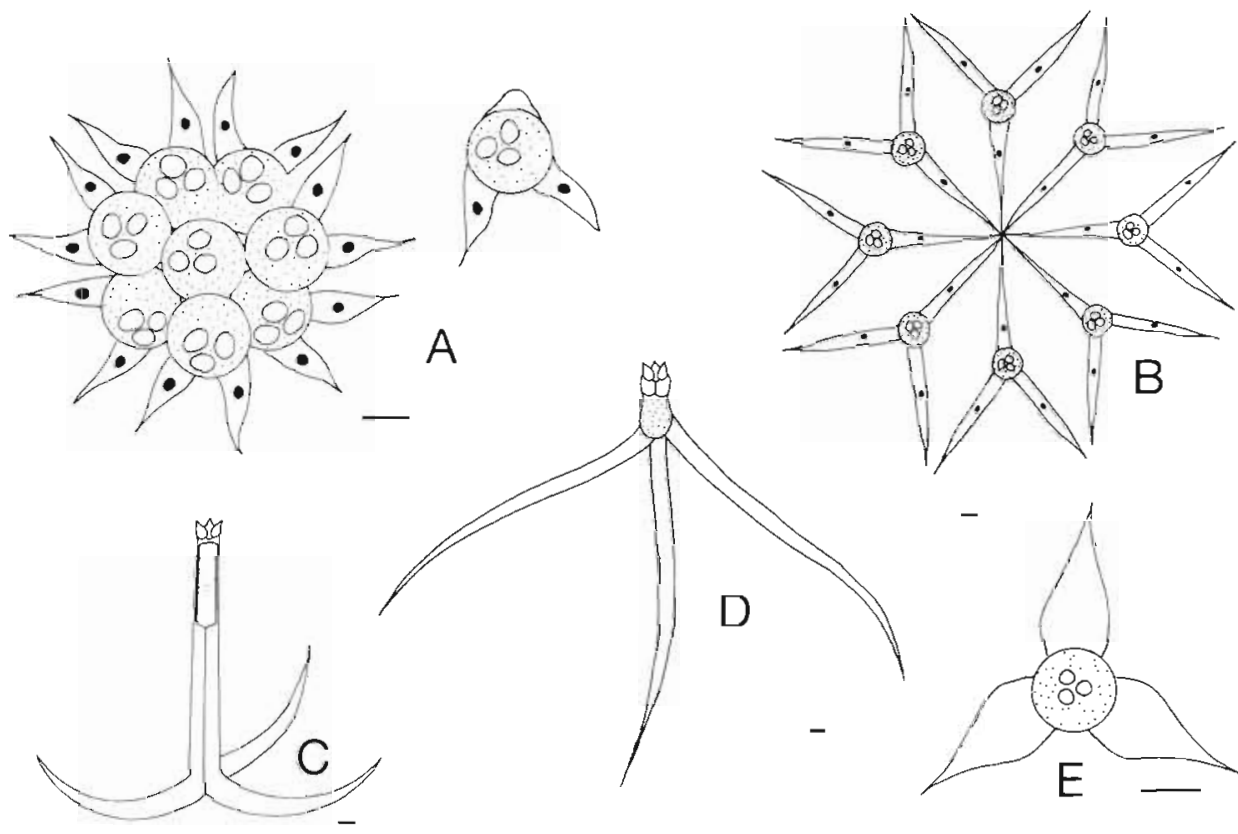

Small pieces of anterior, mid and posterior kidney were immersed in Karnovsky's fixative for 4 to $6 \mathrm{~h}$ at $4{ }^{\circ} \mathrm{C}$. Following post-fixation in $0.5 \%$ osmic acid in cacodylate buffer for $1 \mathrm{~h}$, tissues were dehydrated in an acetone series and embedded in Araldite epoxy resin. Resulting blocks were cut as $1 \mu \mathrm{m}$ semi-thin sections, stained with methylene blue and examined under the light microscope to identify the location of the infection within the worm.

Actinosporean polar filament release and spore hatching. Polar filament extrusion for synactinomyxon, aurantiactinomyxon and raabeia spores was studied in response to the mucus of bream Abramis brama, brown trout Salmo trutta L. and Atlantic salmon Salmo salar L. Water containing actinospores was mixed with an equal volume of mucus obtained via skin scrapes from the fish species concerned, then placed under a coverslip and examined under phase contrast microscopy. Control preparations comprised spores from the same sample to which no mucus had been added.

\section{RESULTS}

\section{Oligochaete sampling}

From the river -2500 oligochaete worms were examined for infection with actinosporeans. These worms were identified to family level, the majority being of the families Tubificidae and Naiidae. Tubificids (a small sample of which proved to be mainly Tubifex tubifex Müller) were characteristic of slower flowing areas of soft substrate, whilst naiids (almost exclusively Nais alpina Sperber) were predominant in areas of stony/rocky substrate and faster flow.

Approximately 2300 worms were obtained from the settlement pond at the farm. A subsample were identified to family, and in some cases generic and species level. The approximate composition of the population varied little between samples, being approximately $70 \%$ Tubificidae, $25 \%$ Lumbriculidae and 5\% Enchytraeidae, with very few naiids present in the settlement pond samples. Because a high proportion of worms were not fully mature, a precise specific identification was impossible in many cases (see Brinkhurst 1963). However, 40 mature tubificid worms studied from the settlement pond sample from June 15, 1993 indicated that the population consisted of 2 species, Tubifex tubifex and Limnodrilus hoffmeisteri Claparède, in a proportion of approximately 5:1. A subsample of 15 lumbriculids were identified as Lumbriculus variegatus Müller.

\section{Actinosporean infections}

Five actinosporeans, of 4 different taxonomic groups (synactinomyxon, raabeia, triactinomyxon and aurantiactinomyxon) were detected from the oligochaetes sampled. All were identified from worms from the settlement pond, but only synactinomyxon ' $A$ ', was found in worms sampled from the river supplying the farm. Prevalence figures are given in Table 2. 
Table 2. Actınosporean prevalence in worm population from the settlement pond, regardless of worm species

\begin{tabular}{|c|c|c|c|c|c|c|}
\hline $\begin{array}{l}\text { Actinosporean } \\
\text { stage }\end{array}$ & $\begin{array}{l}\text { No. of infec- } \\
\text { ted worms found } \\
\text { (whole study) }\end{array}$ & $\begin{array}{c}\% \text { Prevalence } \\
\text { (whole study, } \\
\text { samples combined) }\end{array}$ & $\begin{array}{c}\% \text { Prevalence } \\
\text { (samples where } \\
\text { present) }\end{array}$ & $\begin{array}{l}\% \text { Prevalence } \\
\text { May 14,1993 } \\
\text { (720 worms) }\end{array}$ & $\begin{array}{l}\% \text { Prevalence } \\
\text { June } 6,1993 \\
\text { (384 worms) }\end{array}$ & $\begin{array}{l}\% \text { Prevalence } \\
\text { June } 23,1993 \\
\text { (1152 worms) }\end{array}$ \\
\hline Synactinomyxon 'A' & 4 & 0.18 & 0.26 & 0.00 & 0.50 & 0.20 \\
\hline Synactinomyxon 'B' & 6 & 0.27 & 0.39 & 0.00 & 0.50 & 0.30 \\
\hline Rabeia & 1 & 0.04 & 0.09 & 0.00 & 0.00 & 0.09 \\
\hline Aurantiactinomyxon & 11 & 0.49 & 0.72 & 0.00 & 1.60 & 0.40 \\
\hline Triactinomyxon & 1 & 0.04 & 0.14 & 0.14 & 0.00 & 0.00 \\
\hline
\end{tabular}

\section{Actinosporean morphology and identification}

Table 3 gives a summary of the measurement data for each actinosporean. Although figures for extruded polar filament length are given, in many cases these do not fully evert (Lom \& Noble 1984). Representative illustrations of each spore form are given in Fig. 1.

\section{Synactinomyxon 'A': host Tubifex tubifex}

Released pansporocysts of this actinosporean were observed in which the spores remained enclosed within the sporocyst membrane. In such pansporocysts, caudal processes were not evident (Fig. 2a). When released from ruptured pansporocysts, the caudal processes swelled but the 8 spores within it remained joined together. Two large caudal processes could be clearly discerned for each spore, each containing a nucleus positioned approximately half-way down its length, but the third spore process was obscured. Most commonly, 7 spores were seen to form a circle in the centre of which the eighth spore was positioned, making it impossible to see how the spores were connected. However, in some instances the central spore was absent and it could be seen that the third, conical caudal process of each spore was short, directed centrally, and formed the means by which spores were adjoined to their neighbours (Fig. 2b). Single spores were seen very rarely. Fresh squashes of infected worms revealed large numbers of charac- teristic 8-spore groupings in a star-like arrangement (Fig. 2c). Histological observations indicated that pansporocysts developed in the gut epithelial cells of the worm.

The spore cavity of each spore measured $16.5 \mu \mathrm{m}$ (14-19 $\mu \mathrm{m})$ in diameter, was round, and contained 3 spherical polar capsules of 4-5 $\mu \mathrm{m}$ diameter. The short caudal process linking the 8 spores was $5.2 \mu \mathrm{m}(3-7 \mu \mathrm{m})$ in length, whilst the long process was $18 \mu \mathrm{m}$ $(15-21 \mu \mathrm{m})$ in length. The star-shaped figures formed by the 8 spores were $74 \mu \mathrm{m}(70-80 \mu \mathrm{m})$ in diameter. Polar filaments when extruded formed a spiral with a mean length of $70 \mu \mathrm{m}$ (measurements from a mean of 25 spores).

\section{Synactinomyxon 'B': hosts Tubifex tubifex and Lumbriculus variegatus}

Individual spores of this actinosporean conformed to the characteristics of spores of the collective group echinactinomyxon. Echinactinomyxon spores are styleless with 3 straight, rigid and pointed caudal processes of equal length. However, for the actinosporean under study, spores were always connected together in groups of 8 . These groupings were not of the type characteristic of e.g. siedleckiella or antonactinomyxon (Janiszewska 1955); rather, all 8 were joined together by the tip of one of their caudal processes (Fig. 3a). The spores were thus classified as synactinomyxon (see Marques 1984). Histological observations indicated

Table 3. Summary of measurement data for actinosporeans from the study

\begin{tabular}{|lcccr|}
\hline $\begin{array}{l}\text { Actinosporean } \\
\text { stage }\end{array}$ & $\begin{array}{c}\text { Caudal process } \\
\text { length }(\mu \mathrm{m})\end{array}$ & $\begin{array}{c}\text { Style length } \\
(\mu \mathrm{m})\end{array}$ & $\begin{array}{c}\text { Spore cavity } \\
\text { dimensions }(\mu \mathrm{m})\end{array}$ & $\begin{array}{r}\text { Polar capsule } \\
\text { dimensions }(\mu \mathrm{m})\end{array}$ \\
\hline Synactinomyxon 'A' & $\begin{array}{c}\text { Long: } 18(15-2) \\
\text { Short: } 5.2(3-7)\end{array}$ & - & $16.5(14-19)$ & $5 \times 4$ \\
Synactinomyxon 'B' & $64.4(55-80)$ & - & $21.3(20-23) \times 18.3(16-20)$ & $6 \times 4$ \\
Raabeia & $219.3(170-290)$ & - & $12.8(10-20) \times 18.2(12-25)$ & $6.4(5-8)$ \\
Aurantiactinomyxon & $25.6(19-31)$ & - & $13.7(12-15)$ & $2.7(2-3)$ \\
Triactinomyxon & $129(107-153)$ & $130(110-150)$ & $52(45-60) \times 12.4(12-14)$ & $7 \times 4$ \\
\end{tabular}



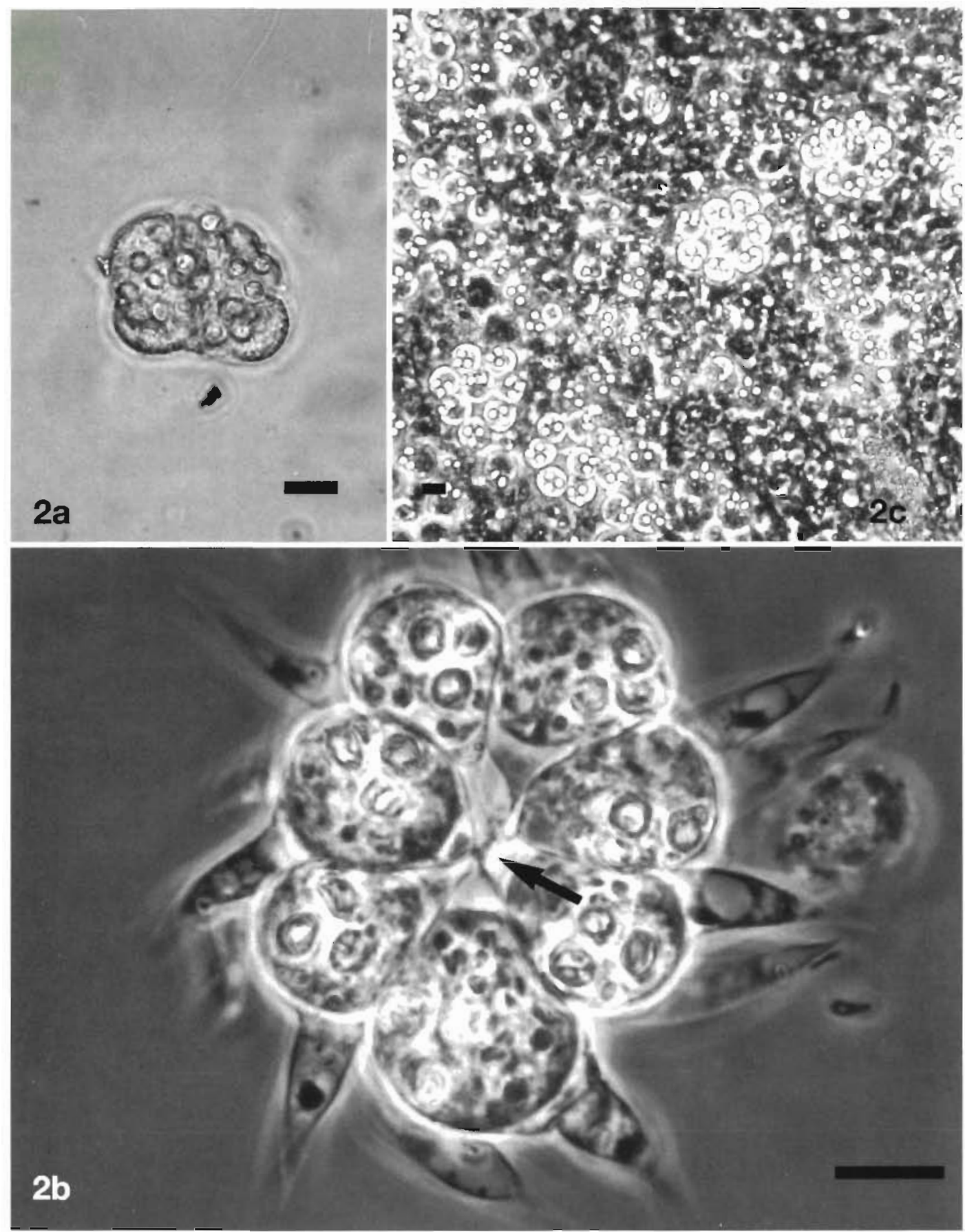

Fig. 2. Synactinomyxon 'A'. (a) Released pansporocyst. (b) Spore web released from the pansporocyst. The caudal processes are fully everted and the junction of the spores by means of their third, short epispore process can be seen (arrow) due to the absence of the eighth centrally positioned spore. (c) Fresh squash preparation of an infected worm to show numerous pansporocysts of synactinomyxon 'A'. (Scale bars $=10 \mu \mathrm{m}$ )

that pansporocysts developed in the gut epithelial cells of the worm. Some sections showed released pansporocysts in the gut lumen.

The spore cavity of individual spores was $18.3 \mu \mathrm{m}$ $(16-20 \mu \mathrm{m})$ at its widest point, but was goblet-shaped with a rounded bottom tapering to $-10 \mu \mathrm{m}$ wide ante- rior surface when viewed laterally. The spore cavity was round when viewed apically. Polar capsules were slightly subspherical (mean $6 \mu \mathrm{m}$ by $4 \mu \mathrm{m}$ ). There were 6 coils of the polar filament in each capsule (Fig. 3b). Extruded filaments were of mean $50 \mu \mathrm{m}$ in length. Caudal processes were straight and of equal length, 
but frequently not fully everted. Fully swollen processes were $64.4 \mu \mathrm{m}(55-80 \mu \mathrm{m})$ in length and $8 \mu \mathrm{m}$ $(6.5-9 \mu \mathrm{m})$ in width before tapering to a fine point (measurements from a mean of 20 spores).

\section{Aurantiactinomyxon: host immature tubificid}

Members of the group aurantiactinomyxon are styleless with 3 broad leaf-like caudal processes of equal width and which curve downwards. Their bases embrace the spore cavity almost entirely (Fig. 4). Spores were always seen singly, released from worms.

The spore cavity was spherical, measuring $13.7 \mu \mathrm{m}$ $(12-15 \mu \mathrm{m})$ in diameter, and contained 3 polar capsules, also spherical, of $2.7 \mu \mathrm{m}(2-3 \mu \mathrm{m})$ diameter. The 3 caudal processes were of equal length, with a mean of $25.6 \mu \mathrm{m}(19-31 \mu \mathrm{m})$ and tapered to a point. Occasional, incompletely inflated caudal processes were rounded at their ends. At their widest point they measured $12.0 \mu \mathrm{m}(10-14 \mu \mathrm{m})$ across. Often each process became broader away from the spore cavity before tapering to a point, giving it a leaf-like appearance. Histological observations indicated that pansporocysts developed in the coelomic cavity and in the gut epithelial cells of the worm (measurements from a mean of 20 spores).

\section{Triactinomyxon: host unidentified}

This parasite was found in a cell well that had been scanned and found to be negative on several occasions over 3 wk. However, the relevant cell well plate had been retained for a further week and then scanned a final time prior to it being discarded. The well contained dead, putrefying worms of unknown species, the spores apparently having been released following the death of the host.

Spores of the collective group triactinomyxon have prominent styles, and 3 long anchor-like caudal projections. The spores were in very poor condition morphologically and were probably senescent or dead. Some changes in spore morphology may therefore have occurred which were not characteristic of living spores.

The spore cavity measured $52 \mu \mathrm{m}(45-60 \mu \mathrm{m})$ by $12.4 \mu \mathrm{m}(12-14 \mu \mathrm{m})$, contained at least 60 daughter cells, and was situated apically beneath the 3 polar capsules at the anterior of the style. Polar capsules were oval, $7 \mu \mathrm{m}$ long by $4 \mu \mathrm{m}$ wide. The style was $130 \mu \mathrm{m}(110-150 \mu \mathrm{m})$ in length and broadened from a width of $\sim 15 \mu \mathrm{m}$ anteriorly to $\sim 25 \mu \mathrm{m}$ at the base where the anchor-like projections arose. These caudal processes were curved, $129 \mu \mathrm{m}(107-153 \mu \mathrm{m})$ in length, but frequently not fully everted (Fig. 5) (mean of 10 spores)

\section{Raabeia: host unidentified}

The raabeia spores were notable for the large size of their caudal processes. Spores of the collective group raabeia are characterised by their 3 long attenuated caudal processes which are usually curved. No style is present, the caudal processes diverging from the equator of the spore cavity. The spore cavity is flask or barrel-shaped

As well as large numbers of free actinospores, numerous released but intact pansporocysts, each containing 8 spores, were found in well water containing infected oligochaetes (Fig. 6a). Upon manual rupturing of the envelope, the spores escaped and their caudal processes rapidly swelled and everted. Numerous spores had incompletely everted processes (Fig. 6b). Histological observations indicated that pansporocysts developed in the gut epithelial cells of the worm.

Caudal processes were very long, curved, and tapered to a point when fully swollen. They were $219 \mu \mathrm{m}$ $(170-290 \mu \mathrm{m})$ by $10 \mu \mathrm{m}$ wide. The spore cavity measured $18.2 \mu \mathrm{m}(12-25 \mu \mathrm{m})$ in length and was $12.8 \mu \mathrm{m}$ $(10-20 \mu \mathrm{m}$ ) in width (Fig. 6c). Polar capsules were pearshaped (mean $7 \mu \mathrm{m} \times 5 \mu \mathrm{m}$ ). Between the sporoplasm and the polar capsules lay a large clear area perhaps containing the cytoplasm of the capsulogenic cells (Fig. 6d). This space was $6.4 \mu \mathrm{m}(5-7 \mu \mathrm{m})$ in length, making the capsule to base of endospore length $24.6 \mu \mathrm{m}(19-30 \mu \mathrm{m})$ (mean of 16 spores). Occasionally aberrant spores were seen with 6 rather than 3 caudal processes arising from a single spore cavity (Fig. 6e).

\section{Stimuli for actinosporean polar filament release and sporoplasm hatching}

Synactinomyxon 'A', synactinomyxon 'B', aurantiactinomyxon, and raabeia discharged their polar filaments in response to the mucus of brown trout, A.tlantic salmon, stickleback and bream (Fig. 7). In all cases eversion was instantaneous and so rarely directly observed as it occurred before the slide could be transferred under the objective, but not every spore in a sample was seen to evert its filaments. Following filament release, many synactinomyxon ' $\mathrm{B}$ ' spores hatched along the suture line around the spore cavity, releasing their sporoplasm into the surrounding medium. Sporoplasms were motile, moving by means of clear pseudopodia with undulating outer membranes (Fig. 7C, inset). Not all spores, even those with everted filaments, hatched to release their sporoplasm. Spores from control preparations occasionally everted their polar filaments, but this was much delayed in comparison with experimental preparations. Eversion could be artificially stimulated mechanically by exerting pressure on the coverslip of a spore preparation. 

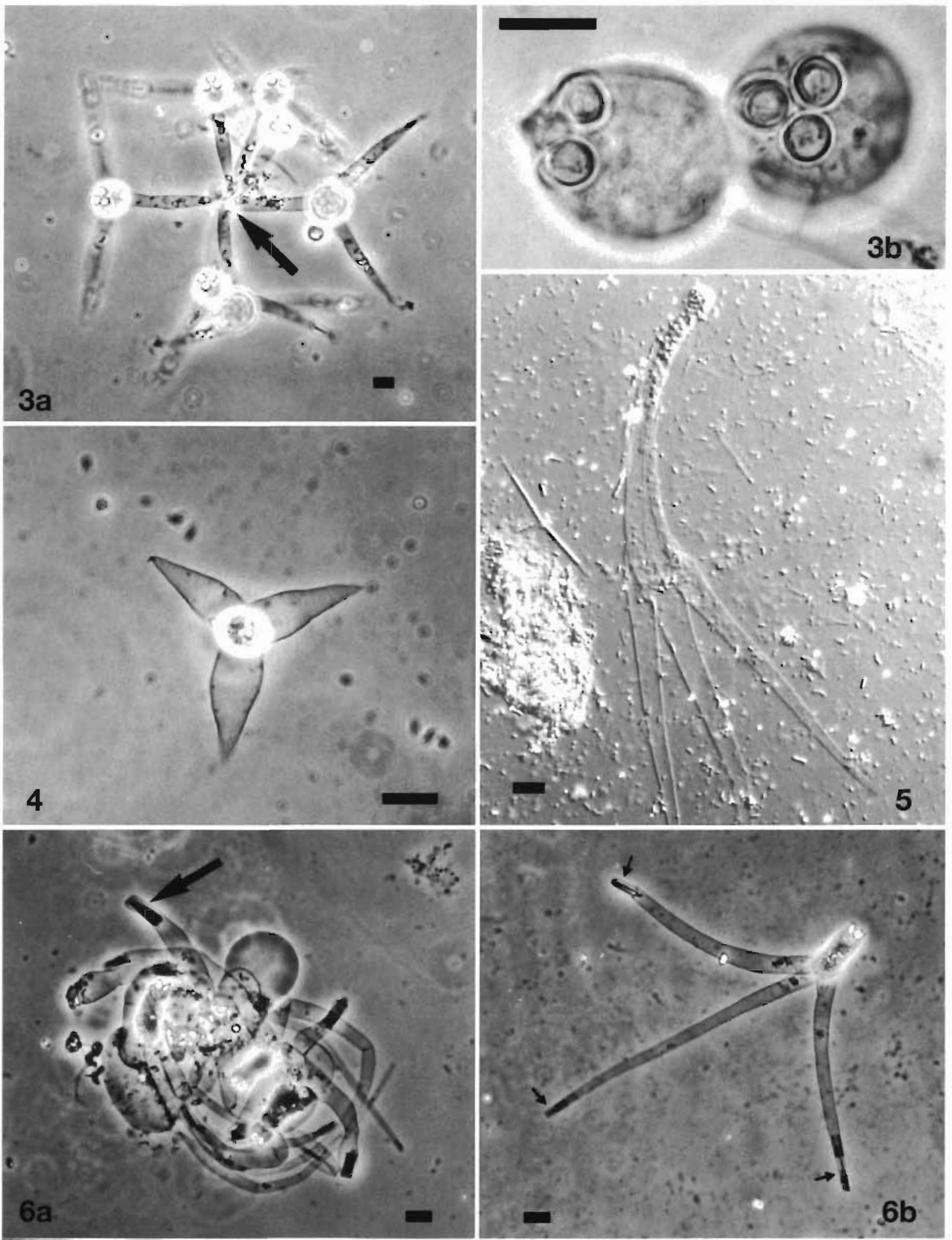

Figs. 3 to 6. Fig. 3. Synactinomyxon longicauda sp. inq. (a) Web formed by spores released from the pansporocyst. The spores connect with each other by means of the tip of one of their epispore processes (arrow). (b) Apex and spore body illustrating the polar capsules. (Scale bars $=10 \mu \mathrm{m}$ ). Fig. 4. Aurantiactinomyxon spore. (Scale bar $=10 \mu \mathrm{m}$ ). Fig. 5. Triactinomyxon mrazeki sp. inq. spore from a cell well containing dead and decaying worms. Note the poor condition of the spore and the presence of numerous bacteria. (Scale bar $=10 \mu \mathrm{m}$ ). Fig. 6. Raabeia: (a) Recently ruptured pansporocyst. The epispore processes of the spores within are beginning to evert (arrow). (b) Spore with incompletely everted epispore processes (arrows). (continued on next page) 

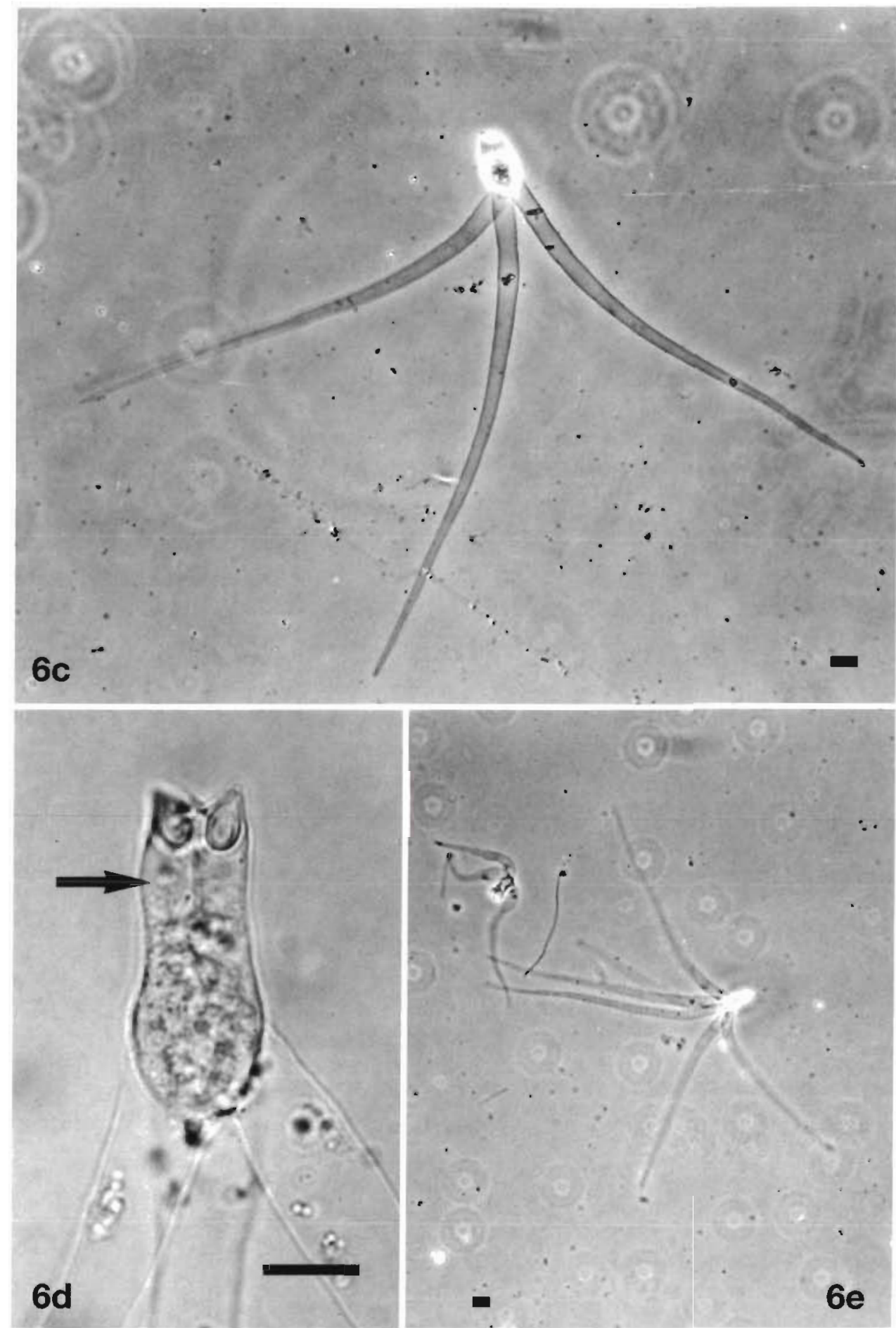

Fig. 6 (continued). (c) Mature released spore with fully everted epispore processes. (d) Apex and spore body of mature spore illustrating the sporoplasm and the gap between the base of the polar capsules and the sporoplasm (arrow). (e) Aberrant spore with 6 epispore processes. (Scale bars $=1.0 \mu \mathrm{m}$ )

Fig. 7. Eversion of polar filaments in response to fish mucus. (a) Synactinomyxon 'A' (b) Raabeia. (c) Synactinomyxon longicauda sp. inq. Inset: released sporoplasm of S. longicauda. (Scale bars $=10 \mu \mathrm{m}$ ) 

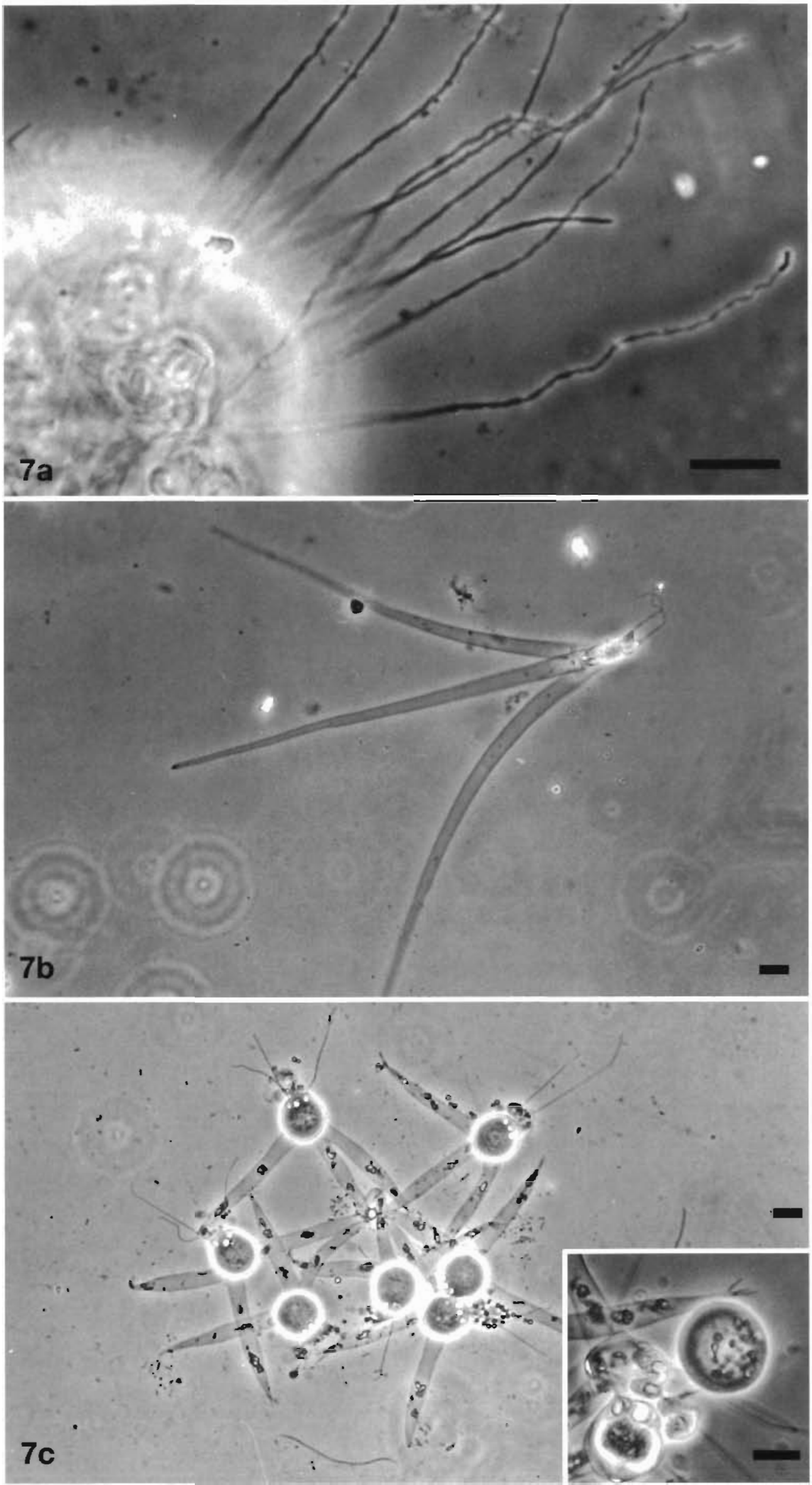


\section{DISCUSSION}

\section{Identity of actimosporeans}

From our developing knowledge of the myxozoan life cycle, it is reasonable to suppose that all 5 actinosporeans identified in the present study have an alternate myxosporean stage in a fish species, although this myxosporean stage remains unknown for each.

\section{Synactinomyxon 'A'}

Synactinomyxon tubificis Stolc, 1899 and S. longicauda Marques, 1984 are found in the gut epithelium of Tubifex tubifex (Janiszewska 1955, Marques 1984) The latter author found both parasites to be relatively common. Synactinomyxon ' $\mathrm{A}$ ' in the present study most closely resembles $S$. tubificis. From the drawings of Janiszewska (1955), the long caudal processes of $S$. tubificis appear around 3 times longer than the diameter of its endospore, but in this study the caudal processes were only fractionally longer than the equivalent diameter. Marques (1984) gave a figure of $30 \mu \mathrm{m}$ for the long caudal processes of $S$. tubificis, significantly longer than the mean $18 \mu \mathrm{m}$ of the Scottish form, and a spore cavity diameter of $12-15 \mu \mathrm{m}$ compared to 14-19 $\mu \mathrm{m}$ for synactinomyxon ' $\mathrm{A}$ '. It is therefore likely that synacinomyxon ' $\mathrm{A}$ ' is not $S$. tubificis, but is a closely related, previously undescribed form. S. tubificis was described by Hamilton \& Canning (1987) from 3 sites in England, but no measurement details or information on its identification were provided.

\section{Synactinomyxon 'B'}

Synactinomyxon longicauda sp. inq. Marques \& Ormieres, 1982 was reported as a common infection of Tubifex tubifex in France (Marques, 1984). The spores of this form resemble echinactinomyxon, but were classified as synactinomyxon because the 8 spores from each pansporacyst were joined by the tip of one of their 3 caudal processes. S. longicauda has a truncated ellipsoid endospore body of $22-25 \mu \mathrm{m}, 80 \mu \mathrm{m} \times$ $8 \mu \mathrm{m}$ epispore floats and $7 \mu \mathrm{m}$ polar capsules. Synactinomyxon ' $\mathrm{B}$ ', although having very slightly smaller capsules and slightly shorter caudal processes on average, is otherwise indistinguishable and is therefore tentatively identified as S. longicauda.

There remains a possibility of confusion between Synactinomyxon longicauda and members of the group echinactinomyxon so a comparison with described species of this group is also pertinent. The type species, Echinactinomyxon radiatum, was described by Jani- szewska (1957) from the gut epithelium of Tubifex tubifex and was recorded from 5 sites in England by Hamilton \& Canning (1987). However, the spore cavity of $S$. longicauda spores is of a different shape to that of E. radiatum and is shorter $(20-23 \mu \mathrm{m}$ compared to 27-30 $\mu \mathrm{m})$. In addition, the caudai processes of $E$. radiatum (125 $\mu \mathrm{m}$ in length compared to the $64.4 \mu \mathrm{m}$ of the form under study) are very much longer. Styer et al. (1992) recorded 2 species of this genus, E. 'major' and E. 'minor' from Dero digitata in the USA. E. 'major' has much longer caudal processes $(138 \mu \mathrm{m})$ than $S$. Iongicauda (55-80 $\mu \mathrm{m})$. E. 'minor' has a similar spore cavity dimension $(19 \times 23 \mu \mathrm{m})$ to the form reported in this study (although in the latter it is of a more rounded shape), but its caudal processes are longer.

\section{Aurantiactinomyxon}

The aurantiactinomyxon stage described in the present study differs from the type species Aurantiactinomyxon raabeiniuoris. Although the epispore processes of $A$. raabeiniuoris are of similar length to those of the aurantiactinomyxon reported here, they are less broad. Its spore cavity diameter is also larger (17 $\mu \mathrm{m}$ compared to $12-15 \mu \mathrm{m}$ ). A. trifolium (Marques 1984) has a much larger spore cavity $(20-25 \mu \mathrm{m})$ than the form under study $(12-15 \mu \mathrm{m})$ and much larger caudal processes $(40-50 \mu \mathrm{m}$ compared to $19-31 \mu \mathrm{m})$. A. stellans (Marques 1984) is also very much larger than aurantiactinomyxon from the present study, having caudal processes of 70-90 $\mu \mathrm{m}$ (compared to 19-31 $\mu \mathrm{m}$ ). Ormieres (1968 cited by Marques 1984) described 2 forms, large and small, of $A$. pavinsis from Stylaria herigianus, but both these forms have markedly shorter caudal processes than the aurantiactinomyxon from Scotland.

The aurantiactinomyxon stages were of particular interest due to their high prevalence at the farm where salmon harbour Sphaerospora truttae infections of high prevalence and intensity. In addition, at least 4, possibly 5 myxosporeans have been shown to have aurantiactinomyxon actinosporean stages. Two species of the genus Aurantiactinomyxon were described from the oligochaete Dero digitata in ponds harbouring proliferative gill disease (PGD) infections by Styer et al. $(1991,1992)$. A. 'major' has a larger spore cavity at 18-22 $\mu \mathrm{m}$, and longer, thinner caudal processes at $11 \times 36 \mu \mathrm{m}$ than the equivalent figures of $12-15 \mu \mathrm{m}$ and $10-14 \mu \mathrm{m} \times 19-31 \mu \mathrm{m}$ for the form reported here. It also differs in having rounded tips to its caudal processes compared to the distinctly pointed ends to the floats of the form under study. The second species, A. 'minor', also possessed rounded tips to its caudal processes. Its spore cavity is of a very similar diameter to that of the 
aurantiactinomyxon from Scotland $(13-16 \mu \mathrm{m})$ but at $36 \mu \mathrm{m}$ it has longer caudal processes.

Comparisons with the aurantiactinomyxon stages of Benajiba \& Marques (1993), El-Matbouli et al. (1992) and of Großheider \& Körting (1992) associated with myxosporean transmissions are not possible since all provide only a single photograph of the species concerned and no measurement data. The Aurantiactinomyxon sp. responsible for Hoferellus carassi infections (El-Matbouli et al. 1992) appears to be very similar to that from Scotland. An unidentified Aurantiactinomyxon was reported but not described by Hamilton \& Canning (1987) from a single UK site, making its comparison with the species from the present study impossible. The aurantiactinomyxon under study therefore appears to be a previously undescribed form.

\section{Triactinomyxon}

Marques (1984) listed 9 species of this genus: Triactinomyxon ignotum; T. magnum; $T$. legeri; $T$. mrazeki; $T$. dubium; $_{T}$. ohridiensis; $T$. petri; $T$. naidanum; and $T$. robustrum. In the UK, T. ignotum and T dubium were recorded by Hamilton \& Canning (1987) and T. ignotum, T. legeri and T. mrazeki by Mackinnon \& Adam (1924). $T$. mrazeki has a style of $\sim 150 \mu \mathrm{m}$, and endospore of 25-65 $\mu \mathrm{m}$ and contains over 50 daughter sporoplasm cells. These measurements are very similar to those of the triactinomyxon from the settlement pond. The Scottish form has a style of 110-150 $\mu \mathrm{m}$, endospore 45-60 $\mathrm{mm}$ and 60+ sporoplasm cells. In addition to the similarity in size, the number of cells in the sporoplasm is of particular significance since $T$. ignotum, $T$. ohridensis, $T$. naidanum, T. magnum, T. legeri and $T$. dubium have only $8,8,12,16,24$, and 32 cells respectively.

The triactinomyxon from the settlement pond at the salmon farm appears identical to Triactinomyxon mrazeki Mackinnon \& Adam, 1924. This differs in size and sporoplasm cell number from the triactinomyxon stage of Myxobolus cerebralis (El-Matbouli \& Hoffmann 1989), and from the triactinomyxon stage of Myxobolus arcticus (Kent et al. 1993). The triactinomyxon stage of the latter species has a shorter style (73.5-82.0 $\mu \mathrm{m}$ compared to $110-150 \mu \mathrm{m})$ but much longer caudal processes (294-360 $\mu \mathrm{m}$ compared to 107-153 $\mu \mathrm{m}$ ) than $T$. mrazeki. It also differs from the triactinomyxon stage of Myxobolus cotti (El-Matbouli \& Hoffmann 1989) since this has just 16 sporoplasm cells and a total style + caudal process length of just $88.64 \mu \mathrm{m}$ on average. Two species of this genus were reported in Styer et al. (1992), T. 'major' and T. 'minor'. Neither possessed a style according to the authors, leading to doubt as to whether their generic identification was correct.
Raabeia

Both Raabeia spp. described by Janiszewska (1957) were identified from the coelomic cavity of oligochaetes: Raabeia magna from Limnodrilus hoffmeisteri and Raabeia gorlicensis from Tubifex tubifex. The endospore cavity of $R$. magna is 51-58 $\mu \mathrm{m}$, much larger than the $24.6 \mu \mathrm{m}$ of the form under study. The barrel shaped spore cavity of $R$ gorlicensis is $35 \mu \mathrm{m}$ long, again larger than that reported here, and it also has longer caudal processes. $R$. furciligera (Jan \& Krzton 1973 cited by Marques 1984) differs from the Scottish raabeia spores by virtue of the 1 to 5 ramified furcae formed at the tips of its caudal processes. The raabeia stage of Myxobolus sp. in goldfish (Yokoyama et al. 1991) has a similar caudal process length $(200 \mu \mathrm{m})$ to that of the raabeia from Scotland (mean $219 \mu \mathrm{m}$, range $170-290 \mu \mathrm{m}$ ), but has a spore cavity of just $9 \mu \mathrm{m}$ diameter and polar capsules of $3.3 \mu \mathrm{m}$, much smaller than their equivalents in the raabeia reported here. The raabeia in the present study therefore appears to be a previously undescribed form.

No reports have previously mentioned the aberrant spores, with 6 rather than 3 caudal processes seen in the present study. Aberrant spores are a common feature of myxosporean development (Shulman 1966).

\section{Relationships of actinosporean infections to Sphaerospora truttae}

Fish species in the river at the farm include wild Atlantic salmon, brown trout, sea trout, eel, and 3spined stickleback. The myxosporean fauna of these fish is not entirely known, but stickleback found in the settlement pond harbour both Sphaerospora elegans and Myxobilatus gasterostei infection (authors' unpubl. obs.). It is therefore impossible to ascribe particular actinosporean stages in the present study to specific myxosporeans.

Of the 5 actinosporean groups reported in this study, only raabeia, triactinomyxon, and aurantiactinomyxon have been shown to date to have a role in myxosporean life cycles. (This does not, of course, rule out the probability that the other actinosporean species found are likely to have myxosporean stages.) Raabeia and triactinomyxon stages have to date been associated with Myxobolus spp. infections in fish (suborder Platysporina: family Myxobolidae). Aurantiactinomyxon stages however have been implicated in PGD (Sphaerospora ictaluri), Hoferellus cyprini, H. carassi, Ceratomyxa shasta and Myxidium giardi infections (sub-order Variisporina). The first 3 myxosporeans are of the family Sphaerosporidae to which Sphaerospora truttae belongs. C. shasta, along with Leptotheca spp., 
is a member of the Ceratomyxidae, a group closely related to Sphaerospora spp. Therefore there appears to be a possible pattern emerging which indicates that platysporine myxosporeans have triactinomyxid type actinosporean stages, whilst variisporine myxosporeans such as Sphaerospora spp. have aurantiactinomyxid type stages. This, combined with the much higher prevalence of aurantiactinomyxon stages at the farm in the present study led to our increased interest in the aurantiactinomyxon as the possible actinosporean stage of $S$. truttae. Currently this actinosporean and the others found at a high prevalence at the farm are the subject of further study.

Polar filaments of a range of actinospores were seen to evert in response to the mucus of salmon, brown trout, stickleback and bream. This indicated that the process may be less specific than would be assumed from Hoffmann et al. (1992), who reported that the actinosporean stage of Myxobolus cerebralis was able to discriminate between naive host fish and those which had previously been infected, and that actinosporeans introduced to the latter fish failed to evert their filaments. Such a system would need to occur at the point of contact between the fish mucus and the polar capsule stopper of the spore, be rapid since the host is fast moving, and be remarkably discriminating. Perhaps the spore forms under study, synactinomyxon 'A' \& 'B', aurantiactinomyxon and raabeia, which evert their polar filaments to a range of fish species' mucus, are the alternate life cycle stages of myxosporeans with broad host specificity, and are not so discriminating. Alternatively they could be species in which host recognition and suitability is not established at the mucus level or is not so precise. Yokoyama et al. (1993) found an intermediate level of response, i.e. although the mucus of several fish species was able to stimulate filament eversion in their actinosporeans, mucus from others would not. This indicates that a definite chemosensory response is present.

Marques \& Ormieres (1982) showed that the sporoplasm of some actinosporeans remained motile for up to $1 \mathrm{~h}$ following their release from spores in petri dishes. In the present study released sporoplasms of synactinomyxon ' $B$ ' showed similar motility. This suggests that the sporoplasm requires a motile ability if it is to actively establish itself in the fish.

Acknowledgements. The authors thank Maureen Menzies for her technical assistance. This work was carned out as part of a N.E.R.C. funded PhD studentship.

\section{LITERATURE CITED}

Benajiba MH, Marques A (1993) The alternation of Actinomyxidian and Myxosporidian sporal forms in the develop- ment of Myxidium giardi (parasite of Anguilla anguilla) through oligochaetes. Bull Eur Assoc Fish Pathol 13:100-103

Brinkhurst RO (1963) A guide for the identification of British Aquatic Oligochaeta. Freshwat Biol Assoc Sci Publ 22:1-52

El-Matbouli M, Fischer-Scherl T, Hoffmann RW (1992) Transmission of Hoferellus carassij Achmerov, 1960 to goldfish Carassius auratus via an aquatic oligochaete. Bull Eur Assoc Fish Pathol 12:54-56

El-Matbouli M, Hoffmann RW (1989) Experimental transmission of two Myxobolus spp. developing bisporogeny via tubificid worms. Parasitol Res 75:461-464

El-Matbouli M. Hoffmann RW, Mandok C (1995) Light and electron microscopic observations on the route of the triactinomyxon-sporoplasm of Myxobolus cerebralis from epidermis into rainbow trout cartilage. J Fish Biol 46:919-935

Großheider G, Körting W (1992) First evidence that Hoferellus cyprini (Doflein, 1898) is transmitted by Nais sp. Bull Eur Assoc Fish Pathol 12:17-20

Hamilton AJ, Canning EU (1987) Studies on the proposed role of Tubifex tubifex (Müller) as an intermediate host in the life cycle of Myxosoma cerebralis (Hofer, 1903). J Fish Dis 10:145-151

Hoffmann RW, El-Matbouli M, Hoffmann-Fezer G (1992) Immunoreactions against the agent of whirling disease in rainbow trout (Oncorhynchus mykiss). International Workshop on Myxosporeans. October 6-8, 1992. Ceské Budĕjovice (abstract only)

Ikeda J (1912) Studies on some sporozoan parasites of sipunculoids. I. The life history of a new Actinomyxidian, Tetractinomyxon intermedium g. et $\mathrm{sp}$. nov. Arch Protistenkd 25:240-242

Janiszewska J (1955) Actinomyxidia. Morphology, ecology, history of investigation, systematics, development. Acta Parasitol Pol 2:405-437

Janiszewska J (1957) Actinomyxidia. II. New systematics, sexual cycle, description of new genera and species. Zool Pol 8:3-34

Kent ML, Margolis L, Corliss JO (1995) The demise of a class of protists: taxonomic and nomenclatural revisions proposed for the protist phylum Myxozoa Grassé, 1970. Can J Zool 72:932-937

Kent ML, Whitaker DJ, Margolis L (1993) Transmission of Myxobolus arcticus Pugachev and Khokhlov, 1979, a myxosporean parasite of Pacific salmon, via a triactinomyxon from the aquatic oligochaete Stylodrilus heringianus (Lumbriculidae). Can J Zool 71:1207-1211

Lom J, Noble E (1984) Revised classification of the class Myxosporea Butschli, 1881. Folia Parasitol 31:193-205

Mackinnon DL, Adam DI (1924) Notes on sporozoa parasitic in Tubifex. I. The life history of Triactinomyxon. Q J Microsc Sci 68:187-209

Marques A (1984) Contribution a la connaissance des Actinomyxidies: ultrastructure, cycle biologique, systematique. PhD thesis, Universite des Sciences et Techniques du Languedoc, Montpellier

Marques A. Ormieres R (1982) La spore des Actinomyxidies Synactinomyxon longicauda n. sp., un nouveau type de groupement sporal et adaptations planctoniques. Emission et structure du sporoplasms. J Protozool 29:195-202

McGeorge J, Sommerville C, Wootten R (1994) Light and electron microscope observations on extrasporogonic and sporogonic stages of a myxosporean parasite of the genus Sphaerospora Thélohan, 1892 from Atlantic salmon, Salmo salar L., in Scotland. J Fish Dis 17:227-239

McGeorge J, Sommerville C, Wootten R (1.996a) The epizootiology of Sphaerospora truttae (Myxozoa: Myxosporea) infections of Atlantic salmon Salmo salar at freshwater 
smolt producing hatcheries in Scotland. Dis Aquat Org 26(1):33-41

McGeorge J, Sommerville C, Wootten R (1996b) Transmission experiments to determine the relationship between Sphaerospora sp. from Atlantic salmon, Salmo salar L., and Sphaerospora truttae (Fischer-Scherl, El-Matbouli \& Hoffmann, 1986): a revised species description for $S$. truttae. Folia Parasitol 43:107-116

Shulman SS (1966) Myxosporidia of the fauna of the USSR Nauka, Moscow (English translation, 1990)

Stolc A (1899) Actinomyxidia; nova skupina Mesozoii pribuzna Myxosporidiim. Rozpr Cesk Akad Cis Fr Jos 8:1-12

Styer EL, Harrison LR, Burtle GJ (1991) Experimental production of proliferative gill disease in channel catfish exposed to a myxozoan-infected oligochaete, Dero digitata. J Aquat Anim Health 3:288-291

Styer EL, Harrison LR, Burtle GJ (1992) Six new species of

Responsible Subject Editor: Wolfgang Körting, Hannover, Germany actinomyxids from Dero digitata. International workshop on myxosporeans. October 6-8, 1992. Ceské Budéjovice (abstract only)

Wolf K, Markiw ME (1984) Biology contravenes taxonomy in the Myxozoa: new discoveries show alternation of invertebrate and vertebrate hosts. Science 255:1449-1452

Yokoyama H, Ogawa K, Wakabayashi H (1991) A new collection method of actinosporeans-a probable infective stage of myxosporeans to fishes-from tubificids and experimental infection of goldfish with the actinosporean Raabeia sp. Gyobyo Kenkyu 26:133-138

Yokoyama H, Ogawa K, Wakabayashi $H$ (1993) Involvement of Branchiura sowerbyi (Oligochaeta: Annelida) in the transmission of Hoferellus carassii (Myxosporea: Myxozoa), the causative agent of kidney enlargement disease (KED) in goldfish Carassius auratus. Gyobyo Kenkyu 28:135-139

Manuscript received: August 7, 1996

Revised version accepted: April 24, 1997 